\title{
Strategies Enhancing Operational Performance of Quality Assurance in Secretarial Work: Nigerian Context
}

\author{
Felix Ogben, Norzaidi Mohd Daud
}

To Link this Article: http://dx.doi.org/10.6007/IJARBSS/v11-i6/10173

DOI:10.6007/IJARBSS/v11-i6/10173

Received: 06 April 2021, Revised: 10 May 2021, Accepted: 30 May 2021

Published Online: 15 June 2021

In-Text Citation: (Ogben \& Daud, 2021)

To Cite this Article: Ogben, F., \& Daud, N. M. (2021). Strategies Enhancing Operational Performance of Quality Assurance in Secretarial Work: Nigerian Context. International Journal of Academic Research in Business and Social Sciences, 11(6), 475-487.

\section{Copyright: @ 2021 The Author(s)}

Published by Human Resource Management Academic Research Society (www.hrmars.com)

This article is published under the Creative Commons Attribution (CC BY 4.0) license. Anyone may reproduce, distribute, translate and create derivative works of this article (for both commercial and non-commercial purposes), subject to full attribution to the original publication and authors. The full terms of this license may be seen at: http://creativecommons.org/licences/by/4.0/legalcode

Vol. 11, No. 6, 2021, Pg. 475 - 487

Full Terms \& Conditions of access and use can be found at http://hrmars.com/index.php/pages/detail/publication-ethics 


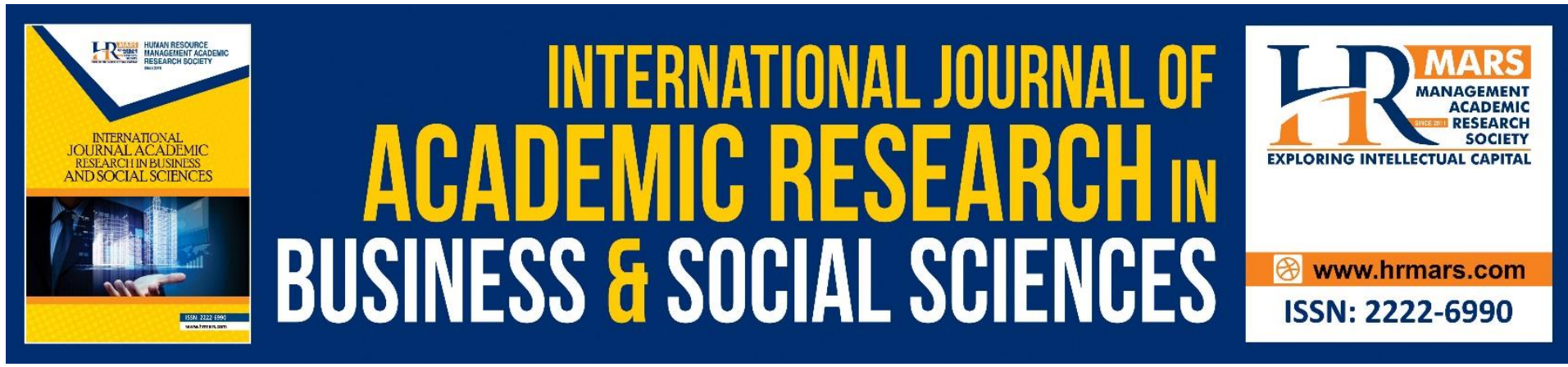

\title{
Strategies Enhancing Operational Performance of Quality Assurance in Secretarial Work: Nigerian Context
}

\author{
Felix Ogben \\ University of Delta, AGBOR, Nigeria/Researcher, Faculti of Business and Management \\ Universiti Teknologi, MARA, Malaysia \\ Email: Felixogben1@gmail.com
}

Prof. (Dr) Norzaidi Mohd Daud

Faculti of Business and Management Universiti Teknologi, MARA, Malaysia

Email: norza544@uitm.edu.my.

\begin{abstract}
This study was conducted using survey design to determine secretarial professionals' rating of strategies required for enhancing operational performance of quality assurance in secretarial work with a lens on Nigeria.62 secretarial professionals drawn from both the private and public sectors across Nigeria constituted the population and sample for the study. The study was guided by a research question and hypothesis. The study utilized a validated four point scale questionnaire with a reliability coefficient of 0.84 using Cronbach Alpha analysis. Mean and standard deviation were used to analyze the data collected to be able to provide answers to the research questions while null hypothesis was tested at 0.05 level of significance using z-test statistic. It was found that the strategies are required for enhancing performance of quality assurance system in secretarial work in Nigeria. The study submits that organizations aiming to improve their firm's performance are expected to implement quality assurance strategies that conform to global standards of practice, and which enable comparability of outcomes, irrespective of industry sector.
\end{abstract}

Keywords: Quality Assurance, Secretarial Work, Secretarial Professional, Operational Performance, Strategy.

\section{Introduction}

In the contemporary office, secretarial professionals are expected to contribute significantly to the goal attainment of the organization by providing the necessary information for management, and also promoting the image of the organization to the outside world. It is against this backdrop that the efficiency and effectiveness of the secretarial staff of any organization are considered paramount in the life of that organization, (Okolocha \& Osahon, 2015). Consequently, employers are in search of secretarial professionals who possess 
requisite knowledge, skills and competencies that would enhance better job performance (Muhammad, 2016).

However, following the advances in technology, office automation and transformation of office procedure, the job of the contemporary secretarial professional has become more varied, complicated, and evolving. Hence, the traditional office skills needed by yesterday's secretarial professionals have become inadequate in today's office environment (Zuin 2012). The traditional task of a secretarial professional which was restricted to typing, taking dictations from the boss and attending to visitors, has become evolving, requiring new skill sets to be relevant (IAAP \& Onifade, 2015).

Today, employers now require top-notch professionals who are technologically savvy and entrepreneurial mindset (Muhammad, 2016). The emerging trend is that the office professional now has an enlarged office schedule requiring the professional, among others, to create spreadsheets, compose correspondences, manage database, and create presentations, report digital graphics, manage inventories, supervise office subordinates, and organize training programmes for office staff (IAAP \& Onifade, 2015). These evolving job demands require new skills sets, improved work attitudes, and an orientation towards organizational survival and customer relationship, to be able to cope with the rising demand for quality outcomes in the haulage of duties (Muhammad, 2016).

Consequently, as stakeholders' continue to enact quality expectations in secretarial work, the incidence of skill mismatch and incompetence on the part of secretarial professionals have become obvious, compelling employers, business and industry, practitioners, and others to voice concern and disappointments over performance decrements, and the high level of skill atrophy bedeviling secretarial work in Nigeria (Kilcoyne, 2003; Muhammad, 2016). These pressures have never been as profound as they now appear, thereby, requiring scholarly attention.

Furthermore, several studies have affirmed that the poor working competencies among secretarial professionals in Nigeria have deprived professionals the right to perform within their schedules of duties, whereas, in most advanced countries, secretarial professionals are given adequate chances to perform their full responsibilities, and are seen as partners who help to enhance organizational performance (ILO, 2008; Muhammad, 2016). A study by Half (2017) found that during downsizing in most organizations in the developed world, leading to job cuts, secretarial professionals are often made to take on the responsibilities of middle management functions in addition, to their regular tasks but in Nigeria, however, stakeholders' confidence in the capability of the secretarial professional to assume higher responsibilities is at the lowest ebb.

However, in order to reverse this downward trend in performance of secretarial professionals, and to reposition secretarial work to be able to contribute to Nigeria's GDP, and restore stakeholders' confidence, so many strategies have been adopted by the relevant government agencies, including the National Board for Technical Education (NBTE), and the National Universities Commission (NUC) which enact quality expectations in various disciplines of study in Nigeria's higher education system. In addition, the Industrial Training Fund (ITF) was established by the Federal Government of Nigeria, to administer the Students Industrial work experience scheme (SIWES) for those undergoing programmes in vocational and technical education (including secretarial) (Ojeaga \& Igbinedion, 2013), and this was followed by the registration of the Association of Professional Staff of Nigeria (APSSON) by the Government to superintend over quality standards in secretarial work. The essence of 
these strategies, is to ensure that the contemporary secretarial professional is equipped with the right knowledge, skills, and attitudes required for being locally relevant and globally competitive (Ojeaga \& Igbinedion, 2013). Yet these strategies appear not to be meeting stakeholders' quality expectations, as quality concerns in secretarial work continue unabated. This gives an indication that the current strategies adopted to enhance operational performance of quality assurance in secretarial work do not appear to be adequately addressing the quality challenges in the occupation in Nigeria.

According to Onyesom and Umoeshiet (2013), strategy is the methodology or process put in place to preserve a product's or service's level of excellence. Strategy as used in quality assurance in secretarial work is a mechanism by which a secretarial work system ensures that the service it delivers or intends to deliver serves the purpose for which it is intended and remains relevant and appropriate to the needs of society. It entails a set of operational techniques and activities that include all actions taken when quality requirements are met (p.142).

Kagumba and George (2013) describe quality assurance as a component of quality management focused on providing confidence that quality specifications will be met (ISO 9000: 2005; Kagumba \& George, 2013). Quality assurance help to build standards, standards and bench-marking are the keys to being a major player in global competitiveness (Suhairo et al., 2015). The conventional function of quality assurance systems is to ensure that organization's quality standards, which are necessary or aspired to, are met and preserved in order to accomplish a specific goal. Hence, quality assurance (QA) systems are designed to monitor and ensure quality (Paintsil, 2016), firms that aim to pursue top-level performance in all processes and functions in order to improve their competitiveness are using quality assurance as a strategy to stay in business (Kagumba \& George, 2013).

Over the past decade, contemporary organizations and institutions in Nigeria have pursued a variety of quality management systems, irrespective of sectors to improve performance, such as Total Quality Management (TQM), M. Baldrige Prize, SGC ISO 9001:2015, EFQM, Ibero-American Prize, the Just-in-Time (JIT) concept, the Deming Award and ISO to maximize performance (Prada Ospina \& Ocampo, 2018). Nonetheless, some scholars have affirmed that, ISO and TQM are the most common quality improvement models (Wanyoike, 2013 \& Kibandi, 2019). The philosophy of quality management practice behind this is that, the core values of TQM systems are quality assurance. These models are international standards of quality management aimed at certifying that a company has adopted the principles of quality assurance or core values as its basis, leading to high performance (Wanyoike, 2013). As a result, many successful firms have implemented these frameworks to enhance the operational performance of their quality management systems (Prada Ospina \& Ocampo, 2018).

Although, findings affirm a positive correlation between the adoption of the principles and strategies of any of these models, and operational performance of quality assurance system in organizations (Ahumuza, 2016; Okelo, 2015; Kibandi, 2019), within Nigeria, there has been little discussion on the various ways that these strategies can be utilized to influence performance of the quality assurance system in secretarial work. This study is therefore, carried out to determine the relationship between these strategies and operational performance, and how these can activate the potentials in secretarial work so that practitioners can contribute to Nigeria's GDP through quality frameworks that are global and enable comparability of outcome in secretarial work. 


\section{Aim/Purpose}

This study aimed to examine the strategies for enhancing the operational performance of quality assurance system in secretarial work in Nigeria.

\section{Problem Statement}

The study problem stems from a lack of knowledge about the strategies that are enhancing the operational performance of quality assurance system in secretarial work in Nigeria. Although several studies have been carried out on the performance of quality assurance system in organizations (Wanyoike, 2013; Ahumuza, 2016 \& Kibandi, 2019), literature allude to the fact, that poor attention has been given to secretarial work (especially in Nigeria), hence this study. This article seeks to answer the question:

1. What are the strategies required for enhancing the operational performance of quality assurance system in secretarial work in Nigeria?

\section{Hypothesis}

The null hypothesis was tested at 0.05 level of significance

1. There is no significant difference in the mean ratings of secretarial professionals in both private and public sectors, on the strategies required for enhancing operational performance of quality assurance system in secretarial work.

\section{Empirical Review on Strategies that are enhancing Operational Performance and Quality Assurance in Secretarial Work}

Operational performance contributes to a company's ability to reduce management costs, order cycle time, deliver orders, enhances effective utilization of raw materials and distribution capability (Truong, Sampaio \& Fernandes, 2014). Operational success is important for businesses, increases manufacturing productivity, produces high-quality goods, satisfies consumers, contributing to improved sales and benefit for businesses (Kaynak, 2003; Kaynak \& Hartley, 2008; Truong et al., 2014).

Feng, Terziovski, and Samson (2008) in Small and Scheme (2011) used a survey instrument to find a positive and meaningful relationship between ISO 9000 standards and operational performance. However, if certification is well-planned and enforced, along with corrective action, annual evaluations, employee training, and dedication, organizational and company efficiency will increase. One drawback of this analysis is that it is only crosssectional. The authors were unable to clarify the time lags between the existence of procedures and their implementation (Small \& Scheme, 2011).

According to Wanyoike (2013 the mission, vision, and objectives of leadership are to promote a quality culture and the development of a set of shared values that lead to high performance. As a result, the importance of top management's full commitment should be understood, communicated, implemented, and maintained at all levels of the organization. Focus should be placed on the importance of quality management practices at the top, where significant dedication to success must be demonstrated through a vision process that includes guiding ideology, core values and beliefs, the intent and mission of the organisation (Wanyoike, 2013).

Several studies on the role of customer focus in orienting organizations towards the product and services dominate contemporary literature on the subject (Vijande \& AlvarezGonzalez, 2007; Toga, 2017)). The findings affirm that customer focus leads to higher 
performance as organizations adapt to evolving customer demands. Customers are economic assets that play a critical role in quality control activities and efficiency despite the fact that they are not on the balance sheet (Baidoun, 2003); \& (Wanyoike, 2013). It is also necessary to listen to the customers and strive to fulfill their needs. The emphasis on firm results or finding customer-driven service is considered by many gurus and writers on the subject of management as a major contributor to the success of organizations (Wanyoike, 2013).

Kaziliunas (2010) and (Wanyoike, 2013) indicated that continuous improvement is a post-certification stage where the management of quality system is carried out. This stage is critical if the business wishes to constantly develop and enjoy the long-term benefits of ISO certification. During post-certification time, a company stands to reap the long-term gains by providing a quality control mechanism that allows it to participate in the continual enhancement of operations, staff preparation and programmes, continuous quality audits and benchmarking. These are all important success drivers for sustainable quality assurance and for the success of ISO certification (Wanyoike, 2013).

Bayazit's (2003) and Mendes (2017) surveyed 250 Turkish organizations the research found that, among other things, employee involvement/commitment and quality training and growth are crucial factors for TQM's successful implementation. These companies are shifting towards a more quality-oriented TQM methodology, so many are adopting training and development initiatives (Mendes, 2017).

\section{Theoretical Framework}

According to Silvermann (2000), theories are the driving force behind research. Theories can also assist in the organization of a collection of concepts in order to define and explain a phenomenon. To define a research problem, concepts are required. Quality improvement theory guided this research (Kimoru \& Kwasira, 2017).

\section{Quality Improvement Theory}

According to Quality Improvement Theory, one aspect of quality management philosophy is that it positions responsibility for production and service processes firmly on top management's shoulders (Deming, 1986; Wanyoike, 2013). As espoused by the theory, management is in charge of operations, while systems are in charge of 80 percent of business issues (Hill, 1995; Wanyoike, 2013). Deming (1986) observed that no quality control system will work without a top management commitment; it is management that invests in systems, establishes a corporate culture, chooses suppliers and maintains long-term relationships. Deming's Quality Improvement Theory gives businesses a strategy for addressing ineffective quality management problems with successful management techniques. It is undeniable that management's actions form organizational culture and determine what matters most to the company's success and survival (Wanyoike, 2013).

Quality systems scholar, Hubert (2000) in Kibandi (2019) have affirmed that Deming's (1986) theoretical approach to the quality management system, envisions the development of an organizational system that fosters collaboration and learning in order to make process management practices easier to enforce. As a result, the processes, goods, and services are continually improved, and employee satisfaction is increased. These are the necessary ingredients for fostering customer focus and, eventually, ensuring a company's survival (Kibandi, 2019). 
Deming (1986) advocated for a methodical approach to problem-solving and popularized the Plan Do Check Act cycle. The Plan Do Check Act (PDCA) cycle of continuous improvement is a fundamental quality improvement philosophy whose aim is to continuously improve performance, reducing the gap between consumer expectations and corporate performance (Goetsch \& Davis, 2006; Wanyoike, 2013). The theoretical essence of the Quality Improvement Theory centres on quality issues in the improvement of an organizational structure that encourages collaboration and learning to facilitate the implementation of process management strategies, which, in turn, leads to success (Wanyoike, 2013). Oakland (2004); Ahumuza (2016) emphasized that senior management's roles should lead the way in improving processes and structures. Leadership plays a crucial role in ensuring the success of quality management because it is the responsibility of top management to develop and communicate a vision to move the firm towards improving performance (Ahumuza, 2016).

According to a study by Lamport et al. (2010; as cited in Wanyoike, 2013) most quality issues can be traced back to top management; it should provide staff with clear instructions about what constitutes satisfactory work and how to accomplish it. These approaches include providing an acceptable working atmosphere and climate for work that is free of guilt, anxiety, or blame, and instead provides clarification of problems, effective communication, and an appropriate work environment to improve results (p.28).

Top management should be committed to implementing the System of Profound Knowledge (SOPK) principles and practices, which enable an organization to simultaneously reduce costs by reducing waste, rework, staff turnover, and litigation while also improving efficiency, customer loyalty, worker satisfaction, and, eventually, profitability (Deming, 1986 \& Wanyoike, 2013).

Deming's Quality Improvement Theory is applicable to this study because quality management techniques are forms of quality assurance mechanisms that can be used to enhance the quality of products and services by corporate organizations to achieve results through continuous improvement. The above assumption is matched against studies by Wanyoike (2013), Kibandi (2015), Okelo (2015), Ahumuza (2016), David (2018), and Ogben and Norzaidi (2021).

\section{Method}

The study adopted the descriptive survey design with 62 secretarial professionals drawn from 6 public institutions and 10 private sector organizations located across Edo and Delta States of Nigeria. The public institutions include: Delta University, Agbor; Delta State University, Abraka; Ika South Local Government Council, Agbor; Federal College of Education (Technical), Asaba; Post-Primary Education Board, Asaba; and Delta State Polytechnic, Ogwashi-Uku. The private sector organizations include: Inter Bau Limited, Asaba; Guinness Nigeria PLC, Zenith Bank PLC, First Bank PLC; The entire study population was used for the study, since the population and not too large and within a management range. There was therefore, no sampling. The questionnaire was the instrument used for data collection. The questionnaire consisted of 15 items based on the objective of the study and research question. The instrument was validated by two lecturers, who have experience in quality assurance in the department of Office Technology and Management, at the University of Delta, Agbor. A pilot study was conducted at Ika South Local Government Council, Agbor, in order to establish the reliability of the instrument. Cronbach Alpha was used to determine the reliability of the instrument which yielded a reliability coefficient of 0.84 . 
To address the research questions, the data was analyzed using the mean and standard deviation. For decision items with a mean range of 3.01 to 4.00 were labelled Strongly Agreed, 2.01 to 3.00 Agreed, 1.01 to 2.00 undecided, and 0.01 to 1.00 Disagreed. The null hypothesis, on the other hand, was evaluated using z-test statistics at the 0.05 level of significance, and the hypothesis was rejected if the calculated $z$-value was equal to or greater than the critical z-value, but not if the calculated z-value was less than the critical z-value. The respondents, on the other hand, completed all 62 questionnaires and returned them to the writers, who were present to collect the questionnaires. This reflects a $100 \%$ return rate, and all of the data was used in the study.

\section{Presentation of Results}

The Mean responses and standard deviation on the strategies required for enhancing operational performance of quality assurance system in secretarial work in Nigeria.

\begin{tabular}{llccc}
\hline S/N & Items & Mean & SD & Remarks \\
\hline 1 & Leadership & 3.48 & 0.22 & Strongly Agreed \\
2 & Customer focus & 3.51 & 0.31 & Strongly Agreed \\
3 & Continuous improvement & 3.16 & 0.52 & Strongly Agreed \\
4 & Employee involvement & 3.63 & 0.24 & Strongly Agreed \\
5 & Process approach & 3.74 & 0.16 & Strongly Agreed \\
6 & Relationship management & 3.09 & 0.68 & Strongly Agreed \\
7 & Evidence-based decision & & & \\
& making & 3.87 & 0.24 & Strongly Agreed \\
& & & \\
\hline
\end{tabular}

The result presented in Table 1 above reveal that all the items have a mean interpretation of strongly agreed. Hence, the strategies are effective in enhancing the operational performance of quality assurance system in secretarial work in Nigeria.

\section{Hypothesis Testing}

$\mathrm{H}_{0} 1$ : The mean ratings of secretarial professionals in both private and public sectors did not differ significantly on the strategies required for enhancing the operational performance of quality assurance system in secretarial work in Nigeria.

Table 2: Summary of z-test Analysis of Null Hypothesis

\begin{tabular}{|c|c|c|c|c|c|c|c|}
\hline Group & $\mathrm{N}$ & $X$ & SD df & z-cal & z-crit & Remark & \\
\hline \multicolumn{8}{|l|}{ Secretarial } \\
\hline Professionals in the & 20 & 3.47 & 0.32 & & & & \\
\hline Private sector & & & & 60 & -0.26 & 2.00 & Not Rejected \\
\hline \multicolumn{8}{|l|}{ Private sector } \\
\hline Secretarial & 42 & 3.49 & 0.34 & & & & \\
\hline \multicolumn{8}{|c|}{ Professionals in the } \\
\hline Public sector & & & & & & & \\
\hline
\end{tabular}


secretarial professionals on the factors enhancing the operational performance of quality assurance system in secretarial work did not differ significantly.

\section{Discussion of Findings}

The study found that the strategies popularized by Prajogo (2011), Martínez-Costa and Martínez-Lorente (2008), (ISO 9000), Wanyoike (2013), and Ogben and Norzaidi (2021) are identified to be effective in enhancing the operational performance of quality assurance system in secretarial work in Nigeria. The findings corroborates that of Wanyoike (2013), Okelo (2015), Ahumuza (2016), Dotong and Laguador (2017), Kibandi (2019), and Ogben and Norzaidi (2021), who assert that a number of organizations are implementing quality assurance as a quality management system to improve productivity, ensure consistent growth, and enhance performance. According to Ogben and Norzaidi (2021) and Wanyoike (2013) quality assurance is a well-structured instrument with which a quality system can be implemented. It shifts the attention of an organization from the quality of final products to the techniques used to produce the goods (p.71). (Gotzamani \& Tsiotras, 2001, as cited in Toga, 2017) noted that the views on its effectiveness and its long-term contribution to the companies implementing it are different. The optimistic view suggests that by implementing the standards, a company benefits by improving the activities of the organization, ensuring consistent and efficient communication, improving the knowledge of employees on quality issues, reducing quality-related costs, and increasing the satisfaction and trust of customers (Toga, 2017).

In fact, a quality assurance system allows an organization to show its commitment to quality and customer satisfaction while also enhancing its operations over time. All organizations should strive to enhance their performance on a continuous basis by implementing a quality assurance system configured around the universal standards (Matata \& Wafula, 2015).

\section{Contribution to the Study}

The contributions to this study are in many dimensions: firstly, it theoretically complements current research on quality management frameworks advanced by ISO 9000 and Wanyoike (2013) by testing their efficacies in an occupation that has a unique circumstance (secretarial work). Secondly, it connects to the existing structure of quality management concepts, procedures, and techniques (Dean, Jr. \& Bowen, 1994; Jason, Elg, Gremyr, \& Wallo, 2021) in an effort to explain the full range of quality improvements and enhancement frameworks required in most organizational settings. Furthermore, this research establishes a theoretical framework and terminology for defining and describing quality management frameworks that address emerging practitioner needs, especially in secretarial work. Studies by (Anttila \& Jussila, 2017; Antony, 2013; Dahlgaard-Park, 2011; Jason et al., 2021) have affirmed that these frameworks are dominant areas of interest for contemporary quality practitioners and researchers alike, and as competencies for facilitating learning in organizations and professional practice.

\section{Limitations}

Despite the fact that the study assessed quality assurance techniques that strengthen secretarial work on a scale of seven dimensions (leadership, customer attention, people participation, continuous improvement, mutually beneficial supplier relationship, process 
management, and factual approach to decision making) as main organizational success measures, it did not exhaustively list activities under these seven dimensions. As a result, not all quality assurance metrics in secretarial work have been included in the study's empirical analysis. Similarly, the extent of stakeholders' participation in quality assurance practice was not investigated in order to make judgments about its adequacy or appropriateness.

\section{Conclusions}

Based on the findings of the study, it was concluded that the need for quality assurance in secretarial work cannot be over-emphasized. Organizations should aim to follow and incorporate a series of best standards that have been effective elsewhere, and that can help them recognize external trends and adapt proactively by continuous improvement to increase performance (Fassoula, 2006 \& Wanyoike, 2013). Continuous improvement implies that there is no fixed threshold for good performance; in the secretarial professional's perspective, it implies that secretarial work, and the environments in which they practice, should never be satisfied with current performance. Since organizational performance is a recurring theme of quality improvement theory and is of great interest to scholars and practitioners, the strategies adopted in this study, are therefore, linked to performance measures in quality assurance system.

\section{References}

Ahumuza, P. (2016). ISO 9001 quality management systems and service delivery in the road sector: A Case of Project Management and Engineering Consultants Limited (PROME). An unpublished masters' thesis submitted to the Ugandan University of Technology and Management.

Al-Asiri, M. M. (2004). "Factors affecting the practices of ISO 9001:2000 quality management system in Saudi business organizations". Electronic Theses and Dissertations, 20042019. 124. https://stars.library.ucf.edu/etd/124.

Ansah, F., Swanzy, P., \& Nudzor, H. P. (2017). Balancing the focus of quality assurance frameworks of higher education institutions in Africa: A Ghanian context. Global Voices in Hgher Education, Susan L. Renes, IntelOpen, Doi.105772/intechopen.686665.

Association of Professional Secretarial Staff of Nigeria. (https://apsson.org.ng/)

Javed, S. (2015). Impact of top management commitment on quality management. International Journal of Scientific and Research Publication, 5(8), 1-5.

Jason, M., Elg, M. H., Gremyr, I., \& Wallo, A. (2021). Towards a quality management

competence framework: exploring needed competencies in quality management. Total Quality Management and Business Excellence.

DOI: 10.1080/14783363.2019.1576516.

Grase, K. (2018). Exploratory case study at one Ontario University. An unpublished PhD thesis submitted to the Ontario university.

Kimoru, K. R., \& Kwasira, J. (2017). Influence of total quality management practices on employee engagement in commercial banks in Nakuru Central Business District, Kenya. International Journal of Economics, Commerce and Management, 5(6), 674-702.

Kyatuha, O. M. (2014). Bureaucracy and decision making in public and private universities in Uganda: A comparative survey. A research proposal submitted to Mbarara University of Technology and management.

Kagumba, A. M., \& George, G. E. (2013). Quality assurance strategy on organizational 
performance: Case of Kenyatta University.European Journal of Business and Management (Online) 5(2), 265-271.

Kibandi, P. (2019). The Factors affecting quality assurance pharmaceutical distributors in Nairobi County. An upublished masters thesis submitted to the University of Strasburg.

Madanat, H. G., \& Khasawneh, A. S. (2017). Impact of total quality management implementation on effectiveness of human resource management in the Jordanian banking sector from employees' perspective. Academy of Strategic Management Journal, 16(1), 114-148.

Martinez-Costa, M., \& Martinez, A. R. (2008). "Does quality management foster or hinder innovation? An empirical study of Spanish firms". Total Quality management and Business Excellence, 19(9), pp 209-221.

Matata, D. J., \& Wafula, M. K. (2015). Effects of quality management systems on performance of Kenya Ports Authority.International Journal of Scientific and Research Publications, 5(5), pp. 1-13).

Nestor, F. O. (2019). Effects of quality management practices on organizational project performance in Kenya: A case of Kirdi, Skisumu, County. An unpublished masters thesis submitted to the University of Nairobi.

Njie, T. L., Fon, T. L., \& Awomodu, G. (2008). Top management commitment and empowerment of employees in TQM implementation. An unpublished Masters thesis submitted to the University of Boras.

Nyakala, K. S., Munyai, T. T., Pretorius, J.-H., \& Vermeulen, A. (2019).Significant factors influencing quality assurance practices in small and medium-sized construction projects in South Africa. Journal of Economics and Behavioral Studies (ISSN: 2220-6140) 11(2), pp. 30-44

Olusanjo, O. D. (2019). Top management commitment to total quality management as a correlate of customer satisfaction in the Nigerian banking sector. Texila International Journal of Management, 35-45.

Okelo, E. A. (2015). Factors affecting quality management standards implementation in Insurance firms in Kenya. An unpublished masters thesis submitted to the University of Nairobi

Okolocha, C., \& Osahon, M. (2015). Professionalism in the secretarial profession. Online ISSN 2411-2933, International Journal of Innvation in Education, 1(2).

Onifade, A. (2015). The secretary and its characteristics. Enems Microsystem Research

Onyesom, M., \& Umoeshiet, E. A. (2013). Strategies considered effective for quality assurance in business education programme in Nigerian universities. Nigerian Journal of Business Education,1(2).

Ooi, K. (2009). TQM and knowledge management:Literature review and proposed framework. African Journal of Business Management, 3(11), pp. 633-643.

Paintsil, R. (2016). Balancing internal and external quality assurance dynamics in higher education institutions: A Case Study of University of Ghana. An unpublished PhD Thesis submitted to the University of Oslo.

Ospina, P. R., \& Ocampo, P. C. (2018). Quality in relation to models and management systems in the automotive sector. A bibliographic review. Espacios, 39(16).

Prajogo, D. I., \& Sohal, A. S. (2004). The multidimensionality of TQM practices in determining quality and innovation performance: An empirical examination. Technovation, 24(6), pp. 443-453. 
Ratsoeu, E., \& Technologiae, M. (2012). The impact of quality assurance systems on the operational performance of laboratories. An unpublished masters thesis submitted to the University of Johanesburg.

Half, R. (2017). How administrative assistants jobs and skills have changed. RH Publications

Small, T., \& Scheme, G. (2011). The Impact of ISO 9000 Certification on Sales : A Case Study of Mauritius Moolna Kawthar \& Sannassee Raja Vinesh. TIPS Small Grant Scheme Research Paper Series 2011

Toga, M. (2017). The relationship between total quality management and innovation in the South African Foundry / Steel Industry. An unpublished masters' thesis submitted to the University of the Witwatersrand, South Africa

Truong, H., Sampaio, P., \& Fernandes, A. C. (2014). The role of quality management practices in operational performance An empirical study in a transitional economy. Proceedings of the 1st International Conference on Quality Engineering and Management.

Wanyoike, R. W. (2013). Quality management practice and firm performance Among manufacuring firms in Kenya. An unpublished PhD Thesis submitted to the University of Kenyatta.

Zubairu, A. A . (2016). Assessment of Quality Management Practices of Building construction firms in Abuja. An unpublished masters Dissertation submitted to the Ahmadu Bello University.

Zuin, D. C. (2012). Revisiting the study of occupations: A holistic view of contemporary secretarial work. An unpublished PhD Thesis submitted to the University of Edinburgh 


\section{Authors Biography}

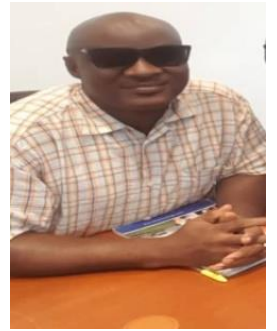

Felix Ogben received B.SC in Business/Secretarial Technology from the Nnamdi Azikiwe, Awka. He also received M.Sc in Secretarial Administration from Imo State University, Owerri; received a Postgraduate Diploma in Computer Science (PGDCS) from the Federal University of Technology, Owerri. He equally received an MBA in HRM from Federal University of Technology, Owerri; and MILR from the Delta State University, Abraka; He is a Tertiary Education Trustfund (TETFUND) Scholar and a Doctoral Researcher in Office Systems Management at the Universiti Teknologi, MARA, Malaysia. He lectures business and information related courses at the University of Delta, Agbor, Delta State, Nigeria.

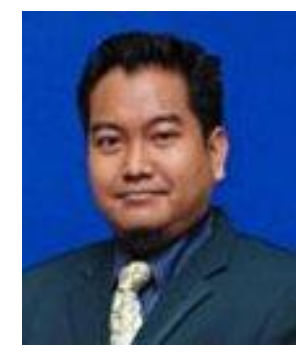

Professor Dr. Norzaidi Hajji Mohd Daud. PhD (MMU), MoM (IIU), BSc (BGSU), Cert. Adv Prob (MMU), Cert. Prob Form \& Prob Formu (MMU). Former Chairman of Community of Research, Institute of Research Management and Innovation (IRMI) at UiTM, and currently, Director of UiTM Press. Prof Norzaidi is a Visiting Professor to so many universities at home and abroad including Widyatama University, Indonesia 2018; King Saud University, Saudi Arabia, 2011-2012.

Management \& Science University, 2018. A Celebrated Academic, Prof Norzaidi is an Adjunct Professor to over eight universities, including his Alma mata, (Multimedia University of Malaysia (MMU).

\section{He has Expertise in}

Structural equation modeling (SEM) using AMOS, publishing article in ISI/SCOPUS listed journals, SPSS and research methodology (postgraduate level), and innovation 